DOSSIER

Copyright $\odot 2011$ SBPJor / Sociedade Brasileira de Pesquisa em Jornalismo

\section{RESEARCH NETWORKS AND VISUALITIES:}

\author{
new settings for journalistic reflection
}

\author{
ROSANE DA SILVA BORGES \\ University of Londrina \\ MIGUEL CONTANI \\ University of Londrina
}

\begin{abstract}
This paper discusses the configurations of research networks in journalism. The focus is on the capillarity of the visual culture and the debates continuously reiterated regarding the epistemological code of communication. Why do newspapers keep investing massively in visual resources, operating structural changes in their make-up? In what name are these graphic-visual changes effected? The confluences between communication and visualities (in the plural in order to cover its immense variety and implications) are, as it seems, a non-deferrable confrontation involving contemporary changes in journalism. The formation of these networks thus relies on a variable and dynamic complexity, in an unlimited territory of exploration where simultaneities, ambiguities, levels of determination and indetermination play an important part. In conclusion, we argue that a theoretical-political principle must be encountered in order for the triad visualities, journalism and communication to be viewed in the ambit of research networks.
\end{abstract}

Keywords: Journalistic Research Networks. Visualities. Communication. Discourses.

\title{
INTRODUCTION
}

\section{Journalism, visualities and research networks}

It has been widely said that printed journalism in particular has undergone key changes as a result of widespread technology. Abundant signs and marks of radical modifications are seen in the ambit of news, as a result of endless innovation made available by the emerging kinds of communication and expression.

Ever more deeply concerned statements dealing with the present and the future of journalistic activity have become frequent - as it is one of the main factors responsible for drawing the outlines that shaped the make-up of modern western societies. Formerly confined 
to academic circles, such manifestations now spring from a variety of sources: researchers, intellectuals, journalists, communication entrepreneurs, publishers go along the same path of reflection, although starting from diversified places and viewpoints, trying to equate the main questions raised in this moment of undefined aspects and successive transformations in the ways of producing news.

Amid this vortex, many analytical prisms volunteer for detailed examination. One that is progressively gaining acceptance is the one that stresses the idea of crisis in order to typify the current phase of journalism. Undoubtedly, the crisis that besets the profession provides the tone of the debate. According to Juan Luis Cebrián, founder and first CEO of El País, what is at stake is the way of doing journalism itself. "The Internet is a phenomenon of de-intermediation. And what future awaits the communication media, as well as political parties and unions, in a deintermediated world?" (O Estado de S. Paulo, May 3, 2010).

If crises are useful for forging creative processes, effecting course corrections, we understand that this moment is an opportunity for the reflections about journalism to renew inquiries that occur in the multifaceted and changing scenario in which we find ourselves. Cebrián ( $O$ Estado de S. Paulo, May 3, 2010) is categorical: "There is no crisis in printed media. There is, indeed, a severe crisis involving the way to do journalism".

No doubt, this "state of the art" prompts the emergence of a number of research works aimed at delineating the scenario briefly mentioned above. Once we start from the understanding that the changes in the ways to do journalism can be credited, to a large extend, to visual and digital codes, it is up to us to determine, within the borderlines of journalistic research, how profound and fundamental these changes are.

Among the queries that form the nucleus, in the field of visual forms, of the theoretical-methodological propositions of study groups, postgraduate programs, research projects and personal endeavors, some appear to be invariable: How can we call for research networks circumscribed to the field of visualities in journalism? What are the possibilities for reflection in order to think about the contemporary journalistic narrative, from the standpoint that it acquires its makeup with the emerging formats (tablets, facebook, youtube, online newspapers, twitter) that make possible the multiple ways of telling stories? How can we establish dialogue with research groups involved with the same thematic?

We can draw from the characteristics of the work on a network, as stated by Whitaker, some edifying lessons: a) autonomy: each member 
maintains his own independence with relation to the network and to the other members. In a network, there is no subordination; b) shared values and goals: what unifies the members of a network is the set of values and objectives they establish as their common practice; c) connectivity: a network is a dynamic seam with many stitches. Only if they are linked to each other do individuals and organizations maintain a network; d) participation: cooperation among members of a network is what makes it function. A network only exists when it is in movement; e) information: in a network, information circulates freely, and is sent from different points and forwarded in a non-linear way to an infinitude of other points that are also information senders; f) decentralization: a network has no center. In other words, each point in the network is a potential center; g) multiple levels: a network can divide into multiple levels or autonomous segments, capable of operating independently from the remainder of the network, in a temporary or permanent way, according to the demand or the circumstance. Sub-networks have the same "network value" as the larger structure to which they are connected; h) dynamism: a network is a plastic structure, dynamic and in movement, that goes across physical or geographical borderlines. A network is multifaceted. Each picture of the network, made at different times, will show a new face. (WHITAKER, 2006, p. 33).

This complex of predicates that typifies networks, far beyond the differences, brings Whitaker closer to thinkers like Gilles Deleuze (1995), Bruno Latour (2008) and Pierre Lévy (1993) himself. Thus, before starting to verify how these predicates apply to the networks of journalistic investigation, a brief detour involving the historical evolution of the term is indicated. The history of the concept of networks starts, as Musso (2004) teaches us, in the ingenious imaginary process of weaving and of the labyrinth.

In ancient times, the medicine of Hippocrates relates it to the metaphor of the body in which "all veins communicate and flow from one to other" (MUSSO, 2004, p.18), but without giving an intrinsic character to the body. Regardless of a relative tradition, the word will achieve expression belatedly in the French language in the XII century, originating from the Latin retiolus, diminutive of retis, and résel in ancient French. From a property outside the body (interlaced threads for fabrics, knitted goods or cloths), the term network takes on a new emphasis, enters into the medical universe and becomes inseparable from the human organism.

From the extensive meaning path tread by Musso, it is worth 
following it up to the conception coined by Saint-Simon, responsible for attributing features that mark its modern stage, that gives it a new nuance of meaning: network is raised to the category of space and time management, an artifact superimposed on a territory; supported by a religious notion (religare/connect), and begins to signify association, communication and communion. Old common places now receive a new meaning, full of consequences for the achievement of ancestral desires of men: the effecting of links - key role of communication - the feedback of utopias about universal connections, of the infinite possibilities of change. A terminological opening is established from that point on that favors an unraveling of the term. It seems clear that the inflation affecting the concept was not beneficial, inasmuch as, still according to Musso, while rich in metaphors, it lacked a consistent concept.

According to André Parente, the notion of network that took the place of the system or of the structure, is fostering such an interest in theoretical and practical works as diverse as science, technology and art, that "we have the impression of facing a new paradigm linked, no doubt, to a thinking of relations as opposed to a thinking of essences." (PARENTE, 2004, p.9)

This quick survey demonstrates that the notion of network itself corresponds to the principle of searching for a clarification that would lead us to establish perspectives, delimit objects and prospect opportunities in the universe of research groups attached to journalism.

In an exercise of confronting Whitaker's characteristics with the topic of visualities and of journalism, some challenges come into play regarding research networks. Even as operators with some of the properties explained by Whitaker, researchers in these interlaced fabrics normally run through areas speckled with ambiguities. The apparent lack of demarcation starts, most of the time, a list of complaints. The difficulties in determining the perimeter of a territory of investigation that satisfies the principal demands of these two vectors (journalism and visualities) encourage the intersection of exploratory fields, since there are no impassable frontiers capable of imposing rigid demarcations on the visual field.

However, we can object, is that not the very nature of work in a network? If, for Latour, the network is at the same time real, collective and discursive, the receiver of heterogeneous elements and perspectives, then it is valid to say that the hybrid is the raw material with which the research groups manipulate (in the sense of shaping) their subjects. If, on one hand, the lack of precise maps which circumscribe the scope of 
visualities constitutes a structural virtue for work in a network, on the other, it encourages its affiliates to think of knots that could make the appropriate link to the development of plural research works based on common intentional horizons.

Deleuze and Guattari's rhizome, a must in terms of discussions on the subject, inspires the protean vocation of the reticular organization and seems to provide signs of response to this inquietude. The six principles of the operation of the rhizome, conceived in its ontological and methodical radicalism, interrogate, equally, the ontological soil and the methodological horizons of the visual artifacts and of the journalistic material as prospective tools for analysis.

As happens with Whitaker's characteristics, let us proceed to a description of the rhizomatous principles: 1) connection (the points of a rhizome can be connected to any other point, deprived of hierarchy, originating from various sides and directions); 2) heterogeneity (decentering over other regions and records); 3 multiplicity (the rhizome is not a unified totality, it is not composed of pure forms); 4) a-significant rupture (a rhizome can be broken or burst; that is the permanent tension between the movement of creating forms and organizations, and of escaping from and undoing these very forms); 5) cartography (synthesizes the methodological principle of the rhizome, points to its inventive and non-representational character); and 6) decalcomania (the principles of tracing are infinitely reproducible, crystallized in codified complexes.

Although not sharing the same repertory of thinkers like Latour (for Deleuze and Guattari, the rhizome does not allow for points, but lines), the theoretical-methodological proposals by these authors meet each other:

\footnotetext{
The Latour network is, at the same time, a way of thinking about the emergence of the hybrids and their own ontology. The elements that the hybrid puts into connection are heterogeneous material, social, technological, linguistic, etc. The connection of the heterogeneous elements is not centralized, hierarchical or assured by any determinism, but is capable, by itself, to engender unedited and unexpected forms that break with previous forms, without the resource to an external force. A hybrid can be a cartographer, in its creative and inventive movement, besides being an arrangement with relation to its "points of structuring" (KASTRUP, 2004, p. 84).
}

Ontological and methodological instances. Deleuze and Latour both engender a concept of network that bears a complexity capable of offering a creative environment for multiple investigative threads of journalistic interrogation. In this interlacing, we find the structuring point of research networks in the vacillating frontiers of communication. The hybrid, more and more manufactured by a set of codes and supports, 
ineluctably creator and inventive, relies on the threads that sustain it. From our speaking place, this thread is the discursive scheme.

Hence, the discursive sphere constitutes one unit (one point) with several facets (heterogeneous) that leads to the coherent (re)building of a reflexive and analytical platform with the power to give shelter to miscellaneous proposals in the contemporary multimedia scene, under the system of the principles of work in a network.

\section{Two previous questions: delimiting frontiers of visuality and of communication}

Keeping track of these inquietudes leads us to adopt, as a conducting thread, the shape of the theoretical territories in which the initiatives for research in network can arise. Extensively divulged, a new visual regime is underway, causing disengagement of theories with canons initially established by the fine arts (namely painting) and, subsequently, by the movies. What we see in our time are meaningful materialities $^{1}$ that with every passing day attain configurations that extrapolate the boundaries of writing, sound and image separately. The reference to meaningful materialities relates to the interwoven codes, originating from several matrices of language.

There is no territory within the domain of multimedia narratives: it is entirely situated on the frontiers (in a galaxy of images, sounds and texts) that go everywhere and cohabit the field of the narration. As stated by Fausto of the Macrocosmos, all is woven into a set, each things acts on the other (CANDIDO, 1996).

It is our opinion that in this set, visuality is the common basis that lends brotherhood to these narrations that include journalistic narratives. If journalism is indeed so permeated by the visual, by the inventive forms of verbal-visual scenes, there are some profound consequences that require that the field of research in the area be equally attentive to the influx of these alterations. These scenes make reference to the field of semiotics and discourse studies, to the constellation of texts going beyond the verbal aspect (sounds, images, gestures, textures, colors) that spring out of the screens, the printed newspapers and other sources.

Well now, if the articulation between research networks concerned with the speedy changes in the journalistic ambit should conceive of the field of visuality as an important vector for analysis, how can knowledge be produced in multidisciplinary territories sheltered under the same umbrella? The topic interacts with already existing fields of knowledge in search for new spaces that are not simply the fusion of already 
consolidated perspectives. All this, as we can notice, brings us back to the discussions about network configuration. We suspect that journalism and the visual, since they overlap, possess the same motivation: to make up for a certain sensation of missing, without which neither the flow of news nor of images come into play in the disputed informative landscape.

The multidisciplinary essence of visualities calls for discussions that provide dimensions for the possible in this marshy region. Visuality theorists such as Dikovitskaya (2005), Catalá (2009), Barthes (1985) and Vilches (1993) report a problem common to all studies and programs circumscribed to the visual sphere: in spite of the undeniable proliferation of research works, there seems to be no consensus within the field itself as to its territory and objectives, definitions and methods.

In spite of this multifarious character, we can delimit the conceptual horizon of visualities and journalism: we understand as visual modalities the forms of representation produced by human beings and organized as language. Although these forms may be sheltered under the umbrella of the term language, indicated in its origin by the Greek term eikon, a welcomer of all kinds of imagery - paintings, prints of a stamp (artificial images), even shadowed and mirrored images (natural) - we consider that the term visuality/visual is more adequate for making reference to the myriad resources constituting the journalistic discourse. The visual is thus related to the different ways to reproduce the "seeing".

The visual discursive heterogeneity also splashes over to the methodological choices. Without any appeal, one problem demands attention: the inevitable complaints from all researchers rest on the overlapping of significants - materialities that overflow, that migrate, that transmute - a characteristic that provides the visual culture its substantive difference and places it at a point that is indiscernible.

However this finding does not hinder the perception of a firm epistemological soil in which visualities can be submitted to the scrutiny of researchers. Indeed, against this verdict, for many a definitive one, it is necessary to dig for other possibilities. As Drummond de Andrade said in the poem Áporo, "an insect digs/digs noiselessly perforating the earth without finding any escape". Such persistency, who knows, may lead us to the drawing of a methodological plan capable of enough investigative power to explain the phenomenon of visualities. Dikovitskaya, in Visual Culture, presents a very comprehensive picture in this area, in the attempt to reconcile the different theoretical positions that hang over the matter and point to its potential for scientific exploration. According to the author, it is necessary to build a specific subject for visualities. The 
lack of this subject ends up by leading this field to incoherence. Although it no longer shares the assumptions of art history, nor is classified only within the limits of the artistic or the aesthetic, a visual theory is built by following the same riverbed that is the construction of the link. Here the notion of link is in partnership with the concept constructed by Sodré. For him, linkage comprises "foreign practices of promotion or maintenance of the social link undertaken by community-centered or collective actions, dialogues etc. (...) the linkage is regulated by diverse forms of communicational reciprocity (affective and dialogical) among individuals (...)" (SODRÉ, 2002, p. 233).

The topic follows us in the constitution of our humanity. Plato, Aristotle, Apel, Habermas, all joined in brotherhood to explore the possibilities and destinations of this linkage (FERRY, 2007). The philosopher Martin Buber considered the word-principle I-You as the first form of human relationship, the I-You relationship is previous to the I itself. For Bubber, "we learn to be humans when called to an I-You relationship - a relationship in which one opens himself totally to the other" (BUBER, 2006, p. 37). It is through the You that the I discovers himself as a nonobject, not reduced to a thing, but as a projection of the other.

A brief observation of the relational/communicational processes will allow us to note that the link between the I and the OTHER is performed to a large extent by the technological artifacts, chiefly by the objects that are available to be seen. The visual empire became what it became by adjusting like a glove to a contemporary demand: it comes to the top of an already defined project with the mechanical image machines (photography and cinema), surpassing both of these image-making devices, since it successfully satisfied, with a strong assistance from the cultural industry, the changes that were taking shape in contemporary society, in which it is desirable that the search for expressivity be stamped on the surface of the world, in the emphasis of the gesture, in grimace of the face, in the eloquence of the voice. All this involves pedagogy, as Xavier recalls, "in that our look is invited to apprehend more immediate forms of recognition of virtue or of sin" (XAVIER, 2003, p. 39).

Then follows the search for other models of investigation that would be capable of covering the deepest processes of its specific reality: the promotion of links, the establishment of social ties. Journalism, in its eternal search for maintenance of the link, seems to adhere, sometimes with no resistance, to society that make images overflow from all its pores. Always more colors, always more sounds, always more images (animated). News making has to give in to the overabundance of visual; 
this adherence also places it above boundaries and also makes it hybrid, but this is not enough to make it devoid of its own principles.

This presumed loss of identity imposes on journalistic research networks an increase in the density of theoretical-methodological discussions, which brings us to dialogue with communication.

\section{In search of a territory in common: communication}

If the association between journalism and visualities appears as an unavoidable conspiracy for the analysis of news making in our times, at the same time as it acts in a de-stabilizing instance, no less peaceful is the place where the association finds shelter: the field of communication. Thus research networks in this territory are irremediably involved in a double challenge: delineating what we have been considering as visualities, an attempt already made in the previous topic, and discerning the territory of communication - a task that still mobilizes a significant range of theories and researchers. Both communication and visuality enjoy a comprehensive, central code, recovering various areas of exploration. Undeniably, both categories take on a cultural density and valence nowadays.

It seems that we are in the very heart of communicative interrogation, since the question of research networks is only legitimate if immediately accompanied by another: what can communication epistemology offer us? The reciprocal dovetailing of the two questions (journalism and visualities), the involvement of each one by the other, is the domain of the reflective attitude in already established research networks. Communicational knowledge is equally an important structuring point.

The fact that one of the main changes in paradigm currently concerns the communicative turnaround which followed hermeneutics, linguistics and pragmatics has become a current position in philosophical circles. Ferry (2007) considers that since Descartes, Kant, Hegel, modern, contemporary philosophy has followed along several paths the different figures of subjectivity and intersubjectivity: figures of consciousness, after reflection, followed by language, and currently by communication. The paradigm of communicative reason constitutes the horizon in which traditional questions of philosophy are permanently updated.

This centrality was not capable of equipping communication with a definitive scientific code. The problem in this field, Sodré (2002) assures us, is still a problem of episteme, of the precarious nature of theoretical and analytical tools.

What would then be the common denominator that makes it possible for advertisements, printed newspapers, radio programs, 
hypermedia texts on the Internet, TV programs, billboards and other things of the sort be analyzed or researched under the same umbrella? This question suggests the formulation of others: Considering the convergences in contemporary media production, from what point is this convergence possible? Which calls for other questions: communication theory is the theory of what? What are communication theories made of? In what field does it fit more appropriately? How can studies and research on the frontiers of this territory be put into effect? What subject defines communicative making?

For Sodré (2002), the determination of a specific subject for communication has been generating permanent doubts. He asks, provocatively: Is it that the department of communication deserves the name of subject, science? What configuration would this area of knowledge have?

The concerns of Sodré (2002) are assiduously present in current discussions referring to the epistemology of communication. We learn from the theoreticians of scientific methodology that there are some criteria and requisites for this or that section of research to be raised to the status of discipline or of science that erects ways of thinking about a certain subject. Then how should the subject of the communication be referred to? The means of access are infinite, but the port of arrival is almost invariably the same. Scholars insist on the uncomfortable situation of the presumed subject of the communication, considered heteroclite and diversified.

The interdisciplinary character would, according to a significant proportion of the researchers in the area, make unfeasible, or in the best case, make difficult the delimitation of the boundaries of the communicative sphere. Unfortunately, we are used to face this essential aspect as something that indefinitely postpones the project of stamping communication as a science or anything of the sort.

Well now, we know that the interdisciplinary aspect is not a problem (or a virtue?) exclusively of communicational knowledge: various disciplines, science and theories have the undisguisable mark of diversity; thus the question dissolves a particular problem of communication. The ubiquity of communication does not correspond to a theoretical postulate of the can-do-it-all, or, still evoking Sodré, the chaos of the subject does not imply the chaos of the theory. Considering the notion of field in Bourdieu (1989), we consider that the specific form of interest in the field of communication is in the way it institutes itself as a discursive institution, amid other fields, equally possessing their own specific forms. 
The logic of competition in the scientific field changes the disciplinary ramifications into specific departments to become differentiated and legitimated faced with the multiplicity of theories and knowledge. And the particularity of the field of communication, we stress, lies in spite of the insistence of several theories and sections of knowledge, in its foundation and discursive organization.

This is not the same as saying that we disregard the political, economic, cultural and social variables involved in the processes of communication. On the contrary: we conceive discourse as embodied in the social area, and therefore a bearer, per se, of the dynamics of which we are all subjects; we know that discourses represent a way of narrating the world and in this way come together with the world to be lived. There is no context on one side and discourse on the other. What is Foucault talking about when he states that the discourse sets up mechanisms of power through its foundationist strength? What is Peirce referring to in his concept of sign, a mediator par excellence? Or even Bakhtin with his notion of sign and discourse? What does Taylor tell us when he says that discourses are interchanges that generate texts, understanding texts as a historically and socially oriented production?

The tenacious persistence in considering the discourse as the fabric that constitutes the plot of journalism, as a central axis for analytical endeavors, occurs by means of a course in which the term (discourse) is reduced to entrancement, means of expression of a final goal. By being entrancement, effectively, it does not attain the stature to explain the capillarity of the communicational phenomenon.

This involves, as before, the discourse. That is the second epistemological effort for research networks: structuring points in the network, discourses are also the central link of the communicative stratum. Taking this point of view requires the construction of methodological operators that could be combined with the principles of the network.

\section{Proposed routes, the paths traveled}

Usually, the method (path to go in search of something) in which a research work is built is determined by the epistemological instance that shapes the investigation premises. Considering that our place of speech is that in which the discourse shows itself as priority nexus for the formation of research networks, what are the routes to be followed? What are the tools to be utilized in research performed in network?

Under the course of epistemological movement (from Descartes to the postmodern reflections), the attempts to discover 
the causes of the world we have before us were marked by a set of orientations and prescriptions, many of them transplanted in the studies of communication, aiming at conquering "the place in the sun" in the scientific world. The word object brings in its etymological root the task of understanding: things must be placed (ject) before us (ob), which allows us to see them, to look at them, treat them as decipherable. But we should not fool ourselves; we cause the effects we want. As Saussure (1995) said, "the point of view creates the object". The established precedent by the Geneva-born linguist provided plausibility to one assertion: We are already, per se, oriented by a faith. Gadamer (2004) shares the same principle as Saussure: striving to free knowledge from the epistemological chains, the philosopher of hermeneutics says that comprehension implies always a pre-comprehension that is in turn prefigured by the tradition determined in which the interpreter (researcher) lives - and where he shapes his previous judgments.

In view of these warnings, we can adopt an attitude of indiscipline, that has a certain amount of the ideas of Feyerabend, author of Against the method:

\begin{abstract}
The conviction that anarchism, even though not being the most attractive political philosophy, is certainly an excellent remedy for the epistemology and for the philosophy of science. [...] History is full of "accidents and situations and curious juxtapositions of events" and shows us the "complexity of human change and the unforeseeable character of the last consequences of any act or decision by men. Should we really believe that the ingenuous and simplistic rules that methodologists take as guides are capable of explaining this "labyrinth of interactions"? (FEYERABEND, 2007, p. 31-2).
\end{abstract}

The anarchy proposed by Feyerabend does not mean, in our case, disdain for methodology, but rather a different layer of dialogue with the heritage of scientific knowledge: "that is, regarding science of social communication it is mandatory that we dare to break with the metaphysics (Aristotelian) of observable facts, where empiricist induction - generated by the traditional dichotomy between theory and observation - has tried to imprison the entire extent of the real. Daring to break, for example, with formulations like that of philosopher Teilhard de Chardin when he wrote that 'it is bad for the sciences to have more ideas than facts"' (SODRÉ, 2002, p. 241).

Something challenges us in this statement by Sodré, provoking us to destabilize models subservient to excessive quantification of facts. To proceed this way will require perhaps a redoubled rigor like the one described by Boudieu in The profession of the sociologist, where he warns that the relativity of the sociologist's knowledge does not justify full 
relaxation, dismissal or laxity. It is a form of rigor that, according to him, aligns with Pascal's wager on a Hidden God, of an uncertain existence and improbable demonstration, but that, in spite of this or, better, because of this, requires a more daring and more radical profession of faith, not always achieved.

These fair warnings make us think. How can we free ourselves from inconveniences of the supremacy of the detailed verification of the world of things as corresponding to the truth, if knowledge - seen as significant-cannot recover its referent, but appears only as a construction of its subject, approximately, without full achievement (therefore there is never any time left for the last word)? How can the studies of communication be more inventive and creative (hybrid, rhizomatous), by adhering to less sterile methodological operators? Would there be escape exits capable of leading us to other forms of investigation?

Let us go on to some model initiatives. Historian Carlo Ginzburg (1989) ventured in the construction of the paradigm of an indicative knowledge, a method for knowledge shored up by minutia, by details, more than by deduction. The famous sentence "Cod is in the particular" synthesizes the Ginzburg method. Alberto Manguel (2006), in his novel The detailer lover, proceeds similarly to Ginzburg: a passionate man, a painter in the early XX Century, delights in the small details of his beloved, seen from a distance (through cracks, door locks) and builds a totality of a woman from traces he is able to gather.

Ginzburg is thus an adept of the conjectural model or hypothetical abducting, where minimal indications reveal more general phenomena. In Ginzburg, Peirce, Morelli, Freud e Sherlock Homes we find a kind of brotherhood: semiotics, psychoanalysis, medicine and police investigation are built on indications, symptoms, not captured by induction or by deduction.

It is equally legitimate and therapeutically healthier for the future of the methodology of communication to adopt an inventive spirit, to trace other routes for analyses. How, then, can we infer some guiding ideas from these orientations? By the possibilities that visualities offer, the answer takes on an indefinite extension.

We thus come closer to the indicial postulate, its basis is in the idea that there will always be something inapprehensible left, without becoming the hostage of obligations that try to respond to the unsolvable questions that visualities reiteratively bring up..

Uncertainties, wide territories, multiple dialogues...To the extent that they pave areas and subareas of investigation, journalistic research 
networks in the field of visualities interrogate, perpetually, the places for knowledge production, updating the discussions that place the scientific knowledge from the departments they are attached to (communication and visualities as is the case here) at the center of the debate. The promotion of links, by means of hyper-image narratives that emerge from informative supports, directs us to observations concerning the legitimacy of journalism in a world that is less and less dependent on it for access and production of the events of the present, that is, in an increasingly de-intermediated world in the words of Célebrian.

\section{Journalism and visualities: new programs of studies for the research networks}

Up to this point we have been considering that conjecturing about the articulation of journalistic research networks in the frontiers of visualities requires that the researcher be attentive to two previous and non-deferrable questions: the theoretical methodological configurations that this enterprise will take on and the tension occurring as a consequence of this. But there is something else. We have not yet taken the following step, which we deem essential, towards an equally important question for the research networks: transposition of visualities far beyond their technological/performational constitution. Reflections on this imply priority.

Why have newspapers kept investing massively in visual resources, making structural changes in their make-up? In what name are these graphic-visual changes effected?

We balance these statements because they appear to offer the bases of a theoretical-political principle in order to compare the triad visualities, journalism, communication, in the ambit of research networks, in the light of the re-accommodations of journalistic practice, involved in providing legitimacy for the processes of mediation established by the news professionals. In a world that information springs from several places, the specialized profession of narrating events in the basis of someone else's report gradually loses importance. In effect, the inventive forms of publication of the facts tend to modify the classic parameters of mediation. With information in real time, we become dizzy with the sophisticated lights, seduced by animated gifs, provoked into tracking with the mouse the springing up of the multiple supplying, always in search of new discoveries, new meanings for living.

Nevertheless, a relief for journalism: the news that is built at the same time of the event in periods of instantaneity needs, besides time for viewing, the time for understanding. Who knows, this time so 
little cultivated in our daily lives, could give a renewed impulse to the means of news production, where visualities would not be only poles of attraction for consumers of texts, but radical promoters of the link based on what is public interest and not interest of the public.

Such hope, no doubt, resembles an exploration program that points to research groups in network, a symptom perceived in most of the world's newspapers. This globalization, in turn, has been motivating a progressive adhesion to broad platforms of discussion concerned with another way of thinking about journalism in a context strongly absorbed by multiple images.

\section{INOTE}

1 Authors of Comparative Literature at Stanford University explore the concepts of what they call theory of the materialities of communication. According to Felinto, "in a first instance, talking about materialities of communication means to bear in mind that all acts of communication demand a material support to become effective. That the communicational acts necessarily involve the intervention of materialities, meanings or means may sound to us like an idea that is already so well-established and natural that it does not need to be mentioned. However, it is precisely this natural character that ends up by hiding diverse aspects and important consequences of materialities in communication - such as the idea that the materiality of the broadcast medium influences and to a certain point determines the structuring of the communicational message". (FELINTO, Erick. www.uff.br/mestcii/felintol .htm. Last access: October 25, 2011 ).

\section{| BIBLIOGRAPHY}

ALVAREZ, Denise. A organização do trabalho na produção acadêmica: redes de pesquisa e estratégias de ação. Rio de Janeiro: mimeo, 2008.

BARTHES, Roland. A aventura semiológica. Lisboa: Ed. du Seuil, 1985.

Crítica e verdade. São Paulo: Perspectiva, 1984.

BORGES, Rosane da S. Ficção e realidade: as tramas discursivas dos programas de TV. 2008, 364f. Tese (Doutorado em Ciências da Comunicação) - Escola de Comunicações e Artes, Universidade de São Paulo, São Paulo.

BOURDIEU, Pierre. O poder simbólico. Lisboa: Difel, 1989.

BUBER, Martin. Do diálogo ao diálogo. São Paulo: Perspectiva, 2006.

BUCCI, Eugênio; KEHL, Maria Rita. Videologias. São Paulo: Boitempo, 
2003. (Coleção Estado de Sítio).

CALLON, Michel. La Science et ses réseaux: genèse et circulation des faits scientifiques. Paris: Editions La Découverte, 2008.

Por uma nova abordagem da ciência, da inovação e do mercado. O papel das redes sócio-técnicas. In PARENTE, André (org.). Tramas da rede. Porto Alegre: Sulina, 2004.

CANDIDO, Antonio. Os parceiros do Rio Bonito. São Paulo: Duas Cidades, 1996.

CATALÁ, Josep. As formas do real. São Paulo: Summus, 2009.

DELEUZE, Gilles; GUATTARI, Félix. Mil platôs: capitalismo e esquizofrenia. São Paulo: Editora 34, 1995. Vol. 1.

DIKOVITSKAYA, Margarita. Visual culture: the study of the visual after the cultural turn. EUA: MIT, 2005.

FELINTO, Erick. <www.uff.br/mestcii/felintol.htm>. Accessed: Oct. 25, 2011.

FERRY, Jean-Marc. Filosofia da comunicação. São Paulo: Paulus, 2007.

FEYERABEND, Paul. Contra o método. São Paulo: Unesp, 2007.

GADAMER, Hans-Georg. Verdade e método II: complementos e índice. Rio de Janeiro: Vozes, 2004.

GINZBURG, Carlo. Mitos, emblemas, sinais: morfologia e história. São Paulo: Companhia das Letras, 1989.

JORNAL “O Estado de São Paulo", 3 de maio de 2010.

KASTRUP, Virgínia. A rede: uma figura empírica da ontologia do presente. In PARENTE, André (org.). Tramas da rede. Porto Alegre: Sulina, 2004.

LATOUR, B; WOOLGAN S. A vida em laboratório: a produção de fatos científicos. Rio de Janeiro: Relume Dumará, 2008.

Jamais fomos modernos. Rio de Janeiro: Editora 34, 1993. In PARENTE, André (org.). Tramas da rede. Porto Alegre: Sulina, 2004.

LÉVY, Pierre. As tecnologias da inteligência. Rio de Janeiro: Editora 34, 1993.

LOPES, Maria Immacolata. Por um paradigma transdisciplinar para o campo da comunicação. São Paulo: ECA/USP, 1998.

MANGUEL, Albert. O amante detalhista. São Paulo: Companhia das Letras, 2006.

MUSSO, Pierre. A filosofia da rede. In PARENTE, André (org.). Tramas da rede. Porto Alegre: Sulina, 2004.

PARENTE, André (org.). Tramas da rede. Porto Alegre: Sulina, 2004.

SAUSSURE, Ferdinand de Saussure. Curso de linguística geral. São Paulo: Cultrix, 1995.

SODRÉ, Muniz. Antropológica do espelho: uma teoria da comunicação linear e em rede. Rio de Janeiro: Vozes, 2002. 
As estratégias sensíveis: afeto, mídia e política. Rio de Janeiro: Vozes, 2006.

VILCHES, Lorenzo. La televisión: los efectos del bien y del mal. Barcelona: Paidós, 1993.

Teoria de la imagen periodística. Barcelona: Paidós, 1987.

WHITAKER, Francisco. Trabalho em rede. São Paulo: mimeo, 2006.

XAVIER, Ismael. O olhar e a cena. São Paulo: Cosac \& Naify, 2003.

Rosane da Silva Borges is $\mathrm{PhD}$ in Communication Sciences from the School of Communications and Arts, University of São Paulo (USP), coordinator of the research project "Visuality news: image, space and design in the game of social representations." She participates in the master's program in Visual Communication at the University of Londrina and coordinates the Center for Afro-Asian Studies at the same university. E-mail: rosanedasb@uol.com.br

Miguel Contani is PhD in Communication and Semiotics at PUC-SP. Researcher in the areas of communication theory, information theory and aesthetics of communication. He participates in master's programs in Communication and Information Science at the University of Londrina (UEL). E-mail: contani@sercomtel.com.br 